\title{
Likuditas Dan Efisiensi Operasional Bank: Bagaimana Peran Moderasi Ukuran BankPerusahaan
}

\author{
Devi Mareta Bowi, dan Maria Rio Rita \\ Fakultas Ekonomika dan Bisnis Universitas Kristen Satya Wacana (UKSW) Salatiga \\ Jl. Diponegoro No. 52-60, Salatiga 50711, Indonesia
}

Info Artikel

Keywords:

Banking Efficiency; Liquidity

bank; and Bank Size.

\begin{abstract}
Abtract
This study empirically examines the effect of liquidity on the efficiency of banking operations in Indonesia, with moderation in company size. To measure the level of operational efficiency, the BOPO ratio is used, which is the ratio of operating costs to operating income and liquidity is proxied by the LDR (Loan to Deposit Ratio) ratio. The sample in this study were 35 state-owned (private) and private (BUSN) banks that listed and published complete financial statements on the Indonesia Stock Exchange for the period of 2016 - 2018. This study proves that LDR has a significant negative effect on (BOPO) and the size of the company moderates / weaken the influence of LDR on BOPO. The greater the size of the bank, the effect of the LDR on operational efficiency will be weaker.
\end{abstract}

Citation: Bowi, D.M. dan Rita, M.R. (2020). Likuiditas Dan Efisiensi Operasional Bank: Moderasi Ukuran Perusahaan. AFRE Accounting and Financial Review, 3 (1)

\begin{abstract}
Abstraks
Studi ini untuk menguji secara empiris efek likuiditas terhadap efisiensi operasional perbankan di Indonesia, dengan moderasi ukuran perusahaan. Untuk mengukur tingkat efisiensi operasional digunakan rasio BOPO, yaitu rasio perbandingan antara biaya operasional dengan pendapatan operasional dan likuiditas diproksikan dengan rasio LDR (Loan to Deposit Ratio). Sampel pada penelitian ini adalah bank 35 pemerintah (BUMN) dan bank swasta (BUSN) yang terdaftar dan mempublikasikan laporan keuangannya secara lengkap di BEI periode 2016-2018. Studi ini membuktikan bahwa LDR berpengaruh negatif signifikan terhadap (BOPO) dan ukuran perusahaan memoderasi/memperlemah pengaruh antara LDR terhadap BOPO. Semakin besar ukuran bank, pengaruh LDR terhadap efisiensi operasional akan semakin lemah
\end{abstract}

JEL Classification: G20, G21

DOI: https://doi.org/10.26905/afr.v3i1.4093
Devi Mareta Bowi:

Tel. /Fax. +62 819-0344-9017

E-mail:

devimareta.107@gmail.com

(cc) BY-NC-SA beragam sumberdaya yang dimiliki dengan optimal agar fungsi intermediasi berjalan dengan optimal.

Kompetisi perbankan nasional saat ini sangat ketat. Efisiensi bank menjadi penentu yang penting agar bank mampu berkompetisi (Zaini, Karim, Chan, \& Hassan, 2010; Paradi \& Zhu, 2013; Subandi \& Ghozali, 2013; Sari \& Widaninggar, 2018; Kamarudin, Sufian, Nassir, Anwar, \& Hussain, 2019; Partovi \& Matousek, 2019, dan (Haryanto, 2020). Bank dengan efisiensi yang rendah akan berdampak pada kinerja bank yang kurang baik. 
Sebagai lembaga keuangan yang memberikan dampak besar terhadap perekonomian, bank harus sehat dan efisien. Sektor perbankan yang efisien akan mampu menahan guncangan negatif dan turut menstabilkan sistem keuangan (Delis \& Papanikolaou, 2009; Salma \& Younes, 2014; Akins, Li, Ng, \& Rusticus, 2016; Ab-hamid, Abdulrahman, \& Abdul, 2018; (Shawtari, Ariff, \& Abdul Razak, 2019, dan Haryanto, Bachtiar, \& Khotami, 2020). Otoritas Jasa Keuangan (OJK) meminta perbankan untuk secara konsisten me-ningkatkan efisiensi, karena dengan meningkatnya efisiensi diharapkan kenaikan bunga kredit bisa terus diredam dan pertumbuhan kredit terjaga (Aldin, 2019). Dengan begitu, kenaikan bunga acuan tidak berdampak negatif terhadap pertumbuhan ekonomi dan kebijakan suku bunga acuan tidak perlu langsung direspon dengan kenaikan bunga kredit oleh perbankan.

Tingkat efisiensi yang dicapai bank dapat diukur dengan membandingkan biaya operasional dengan pendapatan operasional (BOPO). Bank Indonesia dalam ketentuannya, persentase ideal untuk rasio BOPO perbankan nasional berada pada kisaran 60 persen sampai 80 persen. Semakin tinggi rasio $\mathrm{BOPO}$ menunjukkan tingkat efisiensi bank yang semakin rendah. Pada Tabel 1 mempelihatkan nilai efisiensi operasional bank pemerintah dan bank swasta meningkat setiap tahunnya, sehingga perbankan Indonesia dapat dikatakan sudah siap dan mampu bersaing dengan negara ASEAN lainnya. Berdasarkan tabel 1 menunjukkkan efisiensi Bank BUMN lebih tinggi dibandingkan dengan BPD dan juga BUSN.

Tabel 1. Pertumbuhan BOPO Perbankan di Indonesia Periode 2016-2018

\begin{tabular}{lccc}
\hline Jenis Bank & \multicolumn{3}{c}{ BOPO (\%) } \\
\hline Bank Persero (BUMN) & 2016 & 2017 & 2018 \\
Bank Pembangunan Daerah (BPD) & 78,41 & 72,58 & 71,24 \\
Bank Umum Swasta Nasional (BUSN) Devisa & 78,08 & 78,65 & 77,88 \\
Bank Umum Swasta Nasional (BUSN) Non Devisa & 84,58 & 79,93 & 79,72 \\
\hline Sumber: Statistik Perbankan Indonesia (2019) & 91,78 & 90,32 & 88,7 \\
\hline
\end{tabular}

Bank yang berperan menjadi lembaga penghimpun dana masyarakat dan penyalur pinjaman atau kredit, rentan terhadap risiko tingkat likuiditas. Risiko likuiditas merupakan risiko bank dalam menyediakan dana untuk memenuhi kewajiban (Sukarno dan Syaichu 2006; Haryanto, Chandrarin, \& Bachtiar, 2019, dan Susantun, Mifrahi, \& Sudarsono, 2019). LDR menjadi rasio yang digunakan untuk mengukur likuidasi bank dalam jangka pendek dengan membandingkan jumlah kredit dengan Dana Pihak Ketiga (DPK) (Sitompul dan Nasution 2019). Likuiditas bank dalam jangka pendek dapat berupa penarikan dana oleh nasabah dan atau permintaan kredit segera. Oleh karena itu dibutuhkan tingkat likuiditas yang memadai agar bank dapat memberikan pembiayaan dengan baik sehingga bank menjadi lebih efisien. Penyaluran kredit yang lebih besar dibanding dengan deposit/ simpanan masyarakat akan berdampak pada inefisiensi operasional bank karena mengindikasikan bahwa bank tersebut semakin tidak likuid. Hal ini juga dikemukakan oleh Widiarti et al. (2015) yang mengatakan semakin tinggi LDR, bank semakin tidak efisien. Namun berbeda dengan penelitian yang dilakukan oleh Candra dan Yulianto (2015) yang menyatakan bahwa semakin tinggi LDR maka akan meningkatkan efisiensi karena bank akan menerima pendapatan bunga kredit lebih besar selama manajemen mampu mengelola kredit yang telah disalurkan kepada pihak ketiga sehingga tidak terjadi risiko kredit macet.

Di industri perbankan, ukuran atau skala besar kecilnya bank dapat mempengaruhi ting-kat efisiensi, perbedaan ukuran antar bank mengindikasikan tingkat efisiensi yang berbeda. Anwar (2016), (Le, Hoang, Wilson, \& Ngo, 2020) menyimpulkan bahwa ukuran bank merupakan salah satu karakteristik yang sangat penting diperhatikan dalam pengukuran efisiensi bank. Ersangga dan Atahau (2017) menunjukkan terdapat efek dari ukuran bank dalam pengukuran efisiensinya, dimana bank-bank besar cenderung lebih efisien daripada bank-bank kecil. Ǩepková (2014) yang memeriksa efisiensi sektor perbank-an di Ceko menunjukkan bahwa bank berukuran besar kurang efektif jika dibandingkan dengan bank lain karena biaya-biaya yang dikeluarkan untuk menjalankan operasional besar pula. Sedangkan riset yang dilakukan oleh Alber (2015) pada bank di Mesir menyatakan bahwa bank swasta dengan ukuran kecil dan sudah berdiri sejak lama lebih efisien daripada bank publik yang baru saja berdiri dan berukuran besar. Hal tersebut dikarenakan bank yang berpengalaman lebih mampu dalam mengelola operasional dan menangani situasi. Hasil penelitian terkait efisiensi antara bank pemerintah dan bank swasta tidak 
menunjukkan hal yang berbeda (Ersangga \& Atahau., 2017).

Berdasarkan penelitian terkait menunjukkan hasil yang tidak konsisten. Selain itu penggunaan ukuran bank sebagai variabel moderasi antara likuiditas terhadap efisiensi operasional perbankan masih terbatas. Oleh karena itu, penelitian ini akan menempatkan ukuran perusahaan sebagai variabel moderasi yang akan memberikan efek memperkuat atau memperlemah hubungan antara likuiditas bank terhadap efisiensi operasional bank. Ukuran perusahaan me-miliki peran penting dalam menilai efisiensi perbankan, dimana ukuran bank yang berbeda memiliki tingkat likuiditas yang berbeda pula. Penelitian ini bertujuan untuk menguji dan menjelaskan pengaruh likuiditas terhadap efisiensi operasional bank di Indonesia, dengan menambahkan ukuran bank sebagai variabel moderasi dalam model.

\section{PENGEMBANGAN HIPOTESIS}

Puteh et al. (2018) menuliskan bahwa terdapat dua konsep umum efisiensi, yaitu efisiensi ekonomi dan efisiensi produksi. Efisiensi dalam konsep ekonomi memiliki lingkup yang lebih luas dalam hal sudut pandang makro, sementara efisiensi dalam konsep produksi dilihat dari sudut pandang mikro. Konsep produksi dibatasi hanya dengan melihat hubungan dan opera-sional dalam proses produksi, yaitu mengubah input menjadi output (Sutawijaya \& Lestari, 2009). Efisiensi dalam konsep produksi cenderung untuk menilai operasional, sehingga pada umumnya dilihat dari sisi sudut pandang dan biaya.

Kemampuan bank untuk mempertahankan daya saing yang tinggi tercermin dari pelaksanaan operasional yang baik. Daya saing tersebut dapat diukur dengan tingkat efisiensi operasional yang baik serta kemampuan pengelolaan risiko. Dalam Peraturan Bank Indonesia Nomor 14/26/PBI/2012 pencapaian tingkat efisiensi Bank dapat diukur melalui rasio Biaya Operasional terhadap Pendapatan Operasional (BOPO) dan rasio Net Interest Margin (NIM) atau rasio Net Operating Margin (NOM). Pengukuran tingkat efisiensi operasional bank yang digunakan penelitian ini yaitu rasio $\mathrm{BOPO}$, rasio ini dapat menggambarkan efektifitas dan efisiensi bank dalam mengelola input dan output yang dimilikinya. Rasio BOPO yang semakin tinggi menunjukkan biaya operasional yang dikeluar-kan juga tinggi, sehingga semakin tinggi rasio BOPO menyebabkan bank menjadi inefisien.

\section{Likuiditas terhadap Tingkat Efisiensi Operasional Perbankan}

Sebagai lembaga intermediasi, bank bertindak sebagai penyalur kredit kepada pihak yang membutuhkan dana, sehingga pemenuhan likuiditas sangat perlu diperhatikan. LDR menjadi rasio yang mencerminkan alokasi pembiayaan yang disalurkan dari dana yang dihimpun masyarakat dan menjadi rasio dalam menunjukan likuiditas. Thalib (2016) menyatakan LDR yang tinggi menggambarkan penyaluran kredit yang juga tinggi sehingga likuiditas bank akan semakin rendah, sehingga bank tidak dapat memenuhi penarikan dana atau peminjaman kredit mendadak. Oleh karena bank tidak dapat memenuhi kewajiban tersebut, maka akan menurunkan tingkat efisiensi bank. Rasio LDR yang semakin tinggi menunjukkan bank tersebut semakin inefisien. Penelitian yang dilakukan oleh Widiarti et al. (2015), Lutfiana dan Yulianto (2015), serta Zahra \& Darwanto (2019) menemu-kan bahwa LDR berpegaruh negatif terhadap efisiensi bank. Berbeda dengan penelitian yang dilakukan oleh Yusniar (2011), Subandi dan Ghozali (2013), dan Istinfarani \& Azmi (2020) yang menyatakan LDR memiliki pengaruh positif signifikan terhadap efisiensi perbankan. Tingginya nilai LDR menunjukkan kredit yang disalurkan bank lebih tinggi dari dana pihak ketiga yang diterima (DPK), penyaluran kredit yang tinggi mengindikasikan bahwa bank akan menerima pendapatan atas bunga kredit yang lebih besar, dengan meningkatnya pendapatan tersebut maka bank menjadi lebih efisien. Dari penjelasan diatas maka hipotesis satu dinyatakan sebagai berikut:

$\mathrm{H}_{1}$ : Likuiditas berpengaruh terhadap efisiensi operasional perbankan

Likuiditas terhadap Tingkat Efisiensi Operasional Perbankan dengan Ukuran Bank sebagai Variabel Pemoderasi

Ukuran perusahaan merupakan skala besar kecilnya perusahaan yang dapat diukur dengan total aktiva, log size, nilai pasar saham dan lainlain. Pada industri perbankan produk utama bank adalah pembiayaan serta investasi, sehingga ukuran perusahaan atau ukuran bank lebih diproksikan dengan total aset (Firmansyah dan Rusydiana, 2013, dan (Haryanto et al., 2019). Deanna (2013) menyatakan bank yang berskala besar, lebih mampu dalam meminimalkan potensial risiko karena memiliki sumber daya yang lebih banyak, namun tidak dapat menjamin efisiensi dalam operasional- 
nya. Pada penelitian ini ukuran bank menjadi variabel moderasi antara likuiditas terhadap efisiensi operasional bank. Hal ini dikarenakan ukuran bank diharapkan dapat memperkuat atau memperlemah hubungan likuiditas terhadap efisiensi operasional bank. Semakin besar ukuran perusahaan akan memiliki himpunan dana dan tingkat penyaluran kredit yang berbeda sehingga akan berdampak pada rasio LDR dan BOPO. Berdasarkan penjelasan di atas, hipotesis yang diajukan sebagai berikut:

$\mathrm{H}_{2}$ : Ukuran bank memoderasi pengaruh antara likuiditas terhadap efisiensi operasional per- bankan

\section{DATA DAN METODE}

Populasi yang digunakan dalam penelitian ini adalah Bank Umum Pemerintah dan Bank Umum Swasta yang sudah go public di Indonesia periode 2016-2018. Pemilihan sampel dilakukan menggunakan metode purposive sampling dengan kriteria sebagai berikut (1) Bank tersebut sudah go public dan terdaftar di Bursa Efek Indonesia (BEI); dan (2) Bank tersebut mempublikasikan laporan keuangannya secara lengkap (tabel 2).

Tabel 2. Penentuan Sampel Penelitan

\begin{tabular}{lr}
\multicolumn{1}{c}{ Keterangan } & Jumlah \\
\hline Jumlah Bank Umum Pemerintah dan Bank Umum Swasta berdasarkan catatan & 94 \\
Statistik Perbankan Indonesia per Desember 2018 & $(54)$ \\
Perbankan yang belum go public (tidak terdaftar di BEI) & $(5)$ \\
Perbankan dengan laporan keuangan yang tidak lengkap & 35 \\
Jumlah Sampel Penelitian & 35
\end{tabular}

Sumber: Direktori Perbankan Indonesia

Komposisi kelompok bank sebagai sampel dalam penelitian ini disajikan pada tabel 3. Bank Umum Swasta Nasional (BUSN) terdiri dari bank devisa dan bank non devisa.

Tabel 3. Sampel Penelitian

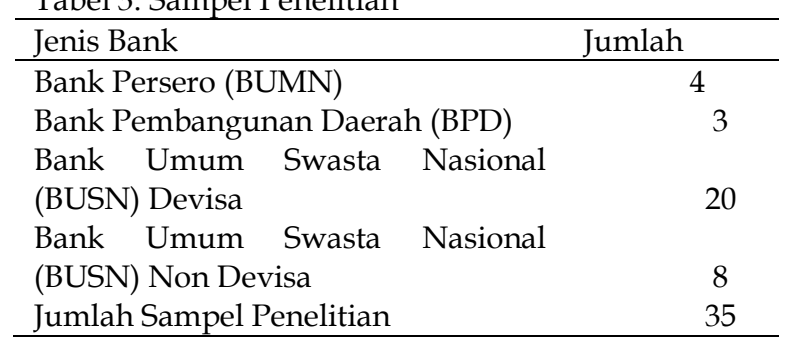

Penelitian ini menggunakan data sekunder berupa laporan keuangan yang meliputi rasio-rasio keuangan, yaitu rasio BOPO dan Loan to Deposite Ratio (LDR). Periode penelitian yang diteliti adalah tahun 2016-2018. Selama periode itu, efisiensi bank secara keseluruhan mengalami peningkatan setiap tahunnya, sehingga menarik untuk diteliti faktor apa yang menyebabkan peningkatan di setiap tahunnya. Perolehan data dilakukan dengan mengakses situs resmi Bursa Efek Indonesia (BEI), yakni: www.idx.co.id.

Variabel dependen pada penelitian ini adalah rasio BOPO sebagai proksi dari tingkat efisiensi operasional, variabel independen LDR sebagai proksi dari likuiditas, dan ukuran perusahaan (Size) sebagai variabel pemoderasi. Semakin tinggi BOPO mengindikasikan efisiensi bank semakin rendah. Operasionalisai variabel disajikan pada tabel 4 .

Teknik analisis yang digunakan adalah regresi linear sederhana dengan moderasi (moderated regression analysis $=$ MRA) untuk mengolah data. Tahapan analisis regresi linear sederhana dengan moderasi yaitu (1) Uji Normalitas; (2) Uji Linearitas; (3) Uji Heterokedastisitas; (4) Uji Autokorelasi; dan (5) Uji Regresi Linear Sederhana.

Berikut persamaan regresi linear sederhana dengan moderasi dalam penelitian ini.

$$
Y=\alpha+\beta 1 X 1+\beta 2(X 1 * M 1)+\varepsilon
$$

Dimana: $\mathrm{Y}=$ Efisiensi Operasional $\mathrm{a}=$ Konstanta, $X_{1}=$ Risiko Likuiditas, $M_{1}=$ Ukuran Perusahaan, $\beta_{1}=$ Koefisien Regresi $X_{1}, \beta_{2}=$ Koefisien Regresi $M_{1}$, e= error.

\section{HASIL}

Dari 35 sampel yang memenuhi kriteria dalam penelitian ini, diperoleh gambaran sampel meliputi nilai minimum, maksimum, rerata dan deviasi standar (tabel 5). Tabel 5 menunjukkan deskriptif statistik data penelitian keseluruhan pada periode 2016- 2018 dengan total sampel (N) sebanyak 98 bank, 98 didapat dari jumlah sampel bank yaitu 35 dikali dengan jumlah periode yaitu 3 dikurangi dengan 7 data outlier, sehingga ditemukan total sampel sebanyak 98 . Nilai minimum dari tingkat efisiensi operasional bank (BOPO) adalah sebesar 0,5784. Nilai BOPO tersebut mengindikasikan bahwa tingkat efisiensi sangat efisiensi. Sedangkan nilai maksimum dari 
tingkat efisiensi operasional bank adalah sebesar 2,3647. Hal ini menunjukkan tingkat efisiensi bank tersebut sangat buruk atau bank paling tidak efisien. Nilai rata-rata dari efisiensi operasional bank adalah sebesar 0,9162 dengan standar deviasi sebesar 0,23917.

Tingkat likuiditas yang diukur menggunakan rasio LDR paling rendah sebesar 0,5076 dan paling tinggi 2,194. Rata-rat LDR sebesar 0,9517. Hal ini menunjukkan bahwa bank-bank mampu menyalurkan dananya cukup tinggi. Semakin tinggi LDR mengindikasikan bank mampu menjalankan fungsi intermediasi dengan baik.

Ukuran perusahaan (Size) yang dilihat dengan Ln=Total Aset. Semakin tinggi aktyiva bank menunnjukkan bak tersebut memliki kemmapuan lebih besar untuk mengembangkan usahanya. Bank yang besar dapat memanfaatkan skala ekonomi, sehingga kecenderungan untuk efisien akan menjadi semakin tinggi.

Tabel 4. Operasionalisasi Variabel Penelitian

\begin{tabular}{|c|c|c|c|}
\hline Variabel & Definisi & Indikator & Sumber \\
\hline $\begin{array}{l}\text { Efisiensi } \\
\text { Operasional }\end{array}$ & $\begin{array}{lr}\begin{array}{l}\text { Kemampuan } \\
\text { ahaan dalam }\end{array} & \begin{array}{r}\text { perus- } \\
\text { men- }\end{array} \\
\text { goptimalkan } & \text { penge- } \\
\text { luaran atau } & \text { biaya } \\
\text { operasional } & \text { untuk } \\
\text { menghasilkan penda- } & \text { pendan operasional. }\end{array}$ & $B O P O=\frac{\text { Biaya Operasional }}{\text { Pendapatan Operasional }} \times 100 \%$ & $\begin{array}{l}\text { Wijayanto dan } \\
\text { Sutarno (2010), } \\
\text { Haryanto (2018) }\end{array}$ \\
\hline Likuiditas & $\begin{array}{l}\text { Risiko bank dalam me- } \\
\text { nyediakan dana untuk } \\
\text { memenuhi kewajiban. }\end{array}$ & $L D R=\frac{\text { Total Kredit }}{\text { Dana Pihak Ketiga }} \times 100 \%$ & $\begin{array}{lr}\text { Sukarno dan } & \text { dyaichu (2006), } \\
\text { Lutfiana dan } & \\
\text { Yulianto (2015) } & \end{array}$ \\
\hline Size & Ukuran perusahaan & $\mathrm{UP}=\mathrm{L}_{\mathrm{n}}$ Total Aset & $\begin{array}{l}\text { Repková (2014), } \\
\text { Deanna (2018), }\end{array}$ \\
\hline
\end{tabular}

Tabel 5. Deskriptif Statistik Variabel Penelitian

\begin{tabular}{|c|c|c|c|c|c|}
\hline Variabel & $\mathrm{N}$ & Minimum & Maximum & Mean & Std. Deviation \\
\hline BOPO & 98 & 0,5784 & 2,3627 & 0,9162 & 0,23917 \\
\hline LDR & 98 & 0,5076 & 2,1694 & 0,9517 & 0,30320 \\
\hline SIZE & 98 & 14,5375 & 20,9832 & 17,3524 & 1,83053 \\
\hline
\end{tabular}

Tabel 6. Hasil Analisis

\begin{tabular}{lrrrl}
\hline & Koefisien & \multicolumn{1}{c}{ Std. Error } & \multicolumn{1}{c}{$\mathrm{t}$} & \multicolumn{1}{c}{ Prob. } \\
\hline (Constant) & 0,858 & 0,035 & 24,545 & 0,000 \\
LDR & 0,499 & 0,113 & 4,431 & $0,000^{* *}$ \\
X1X2 & $-0,028$ & 0,006 & $-4,854$ & $0,000^{* *}$ \\
\hline
\end{tabular}

Catatan: ${ }^{* *}$ signifikan pada level a $1 \%$

\section{Moderated Regression Analysis (MRA)}

Analisis dalam penelitian ini menggunakan uji Moderated Regression Analysis (MRA) yang dapat mengambarkan bagaimana pengaruh size atau ukuran perusahaan sebagai variabel moderasi antara likuiditas dengan efisiensi operasional perbankan. Hasil pengujian dapat dilihat pada tabel 6. Berdasarkan hasil pengujian yang tergambar pada tabel 6 diperoleh persamaan sebagai berikut:

$$
\mathrm{BOPO}=0,858+1,317 \mathrm{LDR}-1,443 \mathrm{LDR} * \mathrm{SIZE}
$$

Berdasarkan persamaan regresi, maka koe- fisien dari LDR adalah positif signifikan dan koefisien interaksi untuk LDR ${ }^{\prime}$ SIZE adalah negatif signifikan. Berdasarkan tabel 5 menunjukkan bahwa likuiditas (LDR) berpengaruh terhadap efisiensi operasional (BOPO) dengan arah positif. Hipotesis pertama diterima. Selanjutnya untuk menguji hipotesis kedua yakni size atau ukuran perusahaan yang digunakan sebagai variabel moderasi juga dapat dilihat pada Tabel 5. Hasil pengujian menunjukkan ukuran perusahaan dapat memoderasi hubungan antara likuiditas dengan efisiensi operasional bank dengan arah negatif (memperlemah). Sehingga hipotesis ke- 
dua diterima dimana variabel ukuran perusahaan dapat memoderasi pengaruh likuiditas terhadap efisiensi operasional dengan status moderasi adalah memperlemah pengaruh antar kedua variabel tersebut.

\section{PEMBAHASAN}

\section{Likuiditas terhadap Tingkat Efisiensi Operasional Perbankan}

Hasil penelitian menunjukkan bahwa likuiditas berpengaruh terhadap tingkat efisiensi operasional bank pemerintah dan bank swasta di Indonesia dengan arah positif. Pada penelitian ini, rasio penilaian likuiditas yang digunakan yaitu rasio LDR. LDR merupakan rasio perbandingan antara jumlah kredit yang disalurkan dengan dana pihak ketiga. Penyaluran kredit yang semakin tinggi menggambarkan likuiditas bank akan semakin rendah, likuiditas yang rendah digambarkan dengan tingginya rasio LDR. Namun kondisi tersebut akan memberikan dampak positif bagi bank karena dengan tingginya rasio LDR menandakan bank akan menerima pendapatan yang tinggi pula atas kredit yang sudah disalurkan, oeh karena itu, efisiensi operasional juga akan semakin meningkat. Hasil penelitian ini mendukung penelitian terdahulu yang dilakukan oleh Yusniar (2011) dan Subandi dan Ghozali (2013) yang menemukan bahwa LDR berpengaruh positif dan signifikan terhadap efisiensi perbankan.

\section{Likuiditas terhadap Tingkat Efisiensi Operasional Perbankan dengan Ukuran Bank sebagai Variabel Pemoderasi}

Hasil penelitian menunjukkan bahwa ukuran perusahaan (size) dapat memoderasi (memperlemah) pengaruh antara likuiditas terhadap tingkat efisiensi operasional. Ukuran perusahaan merupakan faktor yang dapat memberikan efek kepercayaan nasabah untuk menimbun dana atau meminjam kredit dengan melihat besar kecilnya ukuran suatu perusahaan, sehingga berdampak pada tingkat likuditas dari sisi LDR. Ukuran perusahaan yang semakin tinggi akan meningkatkan minat nasabah untuk menabung dan akan mengurangi kepercayaan diri untuk mengajukan kredit karena takut akan proses dan syarat yang semakin rumit. Dengan keadaan dana pihak ketiga yang lebih tinggi dibanding dengan penyaluran kredit, maka akan menurunkan angka rasio LDR yang berarti bank memiliki timbunan dana yang tidak produktif dan menyebabkan bank inefisien dalam mengelola sumber dana yang diperoleh.

\section{SIMPULAN DAN SARAN}

Kesimpulan dari hasil analisis dan pembahasan menunjukkan bahw likuiditas berpengaruh positif terhadap efisiensi operasional bank, dan ukuran perusahaan mampu memoderasi (memperlemah) hubungan likuiditas terhadap efisiensi operasional. Bank dengan ukuran perusahaan yang semakin besar akan menurunkan kepercayaan diri nasabah untuk meminjam kredit, sehingga akan menurunkan angka rasio LDR, menurunnya rasio LDR juga akan menurunkan tingkat efisiensi operasional bank.

Penelitian ini hanya meneliti kinerja efisiensi bank pemerintah (BUMN) dan bank Swasta (BUSN) dengan tidak menguji secara spesifik dampak ukuran perusahaan (small dan big) terhadap kondisi efisiensi perusahaan. Agenda untuk penelitian selanjutnya, dapat menguji lebih komprehensif pengaruh kedua variabel utama dengan memisahkan ukuran banknya melalui dummy variable, baik pengujian khusus pada BUMN ataupun BUSN.

\section{DAFTAR PUSTAKA}

Ab-hamid, M. F., Abdul-rahman, A., \& Abdul-, M. (2018). Bank Market Risk and Bank Efficiency: A Tale from Two Countries. 12(June), 573-584.

Akins, B., Li, L., Ng, J., \& Rusticus, T. O. (2016). Bank Competition and Financial Stability: Evidence from the Financial Crisis. Journal of Financial and Quantitative Analysis, 51(1), 1-28. https://doi.org/10.1017/ S0022109016000090

Alber, N. (2015). Determinants of Banking Efficiency: Evidence from Egypt. International Business Research, 8(8), 50-58. https://doi.org/10.5539/ibr.v8n8p50

Aldin, I. U. (2019). OJK Minta Bank Teruskan Efisiensi untuk Tekan Kenaikan Bunga Kredit.

Anwar, M. (2016). Efisiensi Perbankan di Indonesia: Bank Syari'ah vs Bank Konvensional. Buletin Ekonomi Moneter Dan Perbankan, 18(3), 307-334.

Candra, S., \& Yulianto, A. (2015). Analisis Rasio Keuangan Terhadap Tingkat Efisiensi Bank Umum Syariah (Two Stage SFA). Accounting Analysis Journal, 4(4), 1-9. 
Deanna, J. N. (2018). Determinan Efisiensi Operasional Perbankan Indonesia (Studi Empiris pada Perbankan Umum Konvensional di Indonesia Tahun 20112016). Jurnal Muara Ilmu Ekonomi Dan Bisnis, 2(1), 217. https://doi.org/10.24912/jmieb. v2i1.1554

Delis, M. D., \& Papanikolaou, N. I. (2009). Determinants of bank efficiency: evidence from a semi-parametric methodology. Managerial Finance, 35(3), 260-275. https://doi.org/10.1108/0307435091093177 1

Ersangga, D., \& Atahau., A. D. R. (2017). Perbandingan Efisiensi Bank Umum Pemerintah dan Bank Umum Swasta dengan Pendekatan Data Envelopment Analysis. Modus, 31(1), 72-88.

Ersangga, D., \& Atahau, A. D. R. (2017). Perbandingan Efisiensi Bank Umum Pemerintah dan Bank Umum Swasta dengan Pendekatan Data Envelopment Analysis. MODUS, 31(1), 72-88.

Firmansyah, I., \& Rusydiana, A. S. (2013). Pengaruh Profitabilitas Terhadap Pengeluaran Zakat Pada Bank Umum Syariah di Indonesia Dengan Ukuran Perusahaan Sebagai Variabel Moderasi. Jurnal Liquidity, 2(2), 110-116.

Haryanto, S. (2018). Determinan Efisiensi Bank: Analisis Bank Di Indonesia. AFRE (Accounting and Financial Review), 1(1), 4652. https://doi.org/26.82017/JKP.2017.001

Haryanto, S. (2020). Efficiency , Risk and Profitability of Islamic Banks: Under Pressure in the Competition of the Banking Industry in Indonesia. 2020, 474-482. https://doi.org/ 10.18502/kss.v4i9.7345

Haryanto, S., Bachtiar, Y., \& Khotami, W. (2020). Efficiency and Rentability of Islamic Banks in Indonesia. Inovator Jurnal Manajemen, 9(1), 41-48. https://doi.org/10.1166/asl. 2017.9975

Haryanto, S., Chandrarin, G., \& Bachtiar, Y. (2019). Bank Size, Risk and Market Discipline with A Deposit Insurance: Evidence of Banking in Indonesia. AFRE (Accounting and Financial Review), 2(2), 8190. https://doi.org/10.26905/afr.v2i2.3717

Istinfarani, S., \& Azmi, F. (2020). Faktor Penentu Tingkat Efisiensi Kinerja Perbankan. Jurnal Akuntansi Dan Pajak, 20(2), 230-240. https://doi.org/10.29040/jap.v20i2.800

Kamarudin, F., Sufian, F., Nassir, A. M., Anwar,
N. A. M., \& Hussain, H. I. (2019). Bank Efficiency in Malaysia a DEA Approach. Journal of Central Banking Theory and Practice, 8(1), 133-162. https://doi.org/10.2478/ jcbtp-2019-0007

Le, M., Hoang, V. N., Wilson, C., \& Ngo, T. (2020). Risk-adjusted efficiency and bank size in a developing economy: an analysis of Vietnamese banks. Journal of Economic Studies, 47(2), 386-404. https://doi.org/ 10.1108/JES-12-2018-0425

Lutfiana, Rosyiqoh Haida dan Yulianto, A. (2015). Determinan Tingkat Efisiensi Bank Umum Syarih Di Indonesia (Pendekatan Two Stage DEA). Accounting Analysis Journal, 4(3), 1-6. https://doi.org/ISSN 2252-6765

Paradi, J. C., \& Zhu, H. (2013). A survey on bank branch efficiency and performance research with data envelopment analysis. Omega (United Kingdom), 41(1), 61-79. https:/ / doi.org/10.1016/j.omega.2011.08.0 10

Partovi, E., \& Matousek, R. (2019). Bank efficiency and non-performing loans: Evidence from Turkey. Research in International Business and Finance, 48(December 2018), 287-309. https://doi.org/10.1016/j.ribaf.2018.12.011

Puteh, A., Rasyidin, M., \& Mawaddah, N. (2018). Islamic Banks in Indonesia: Analysis of Efficiency. 331-336. https://doi.org/ 10.1108/978-1-78756-793-1-00062

Řepková, I. (2014). Efficiency of the Czech Banking Sector Employing the DEA Window Analysis Approach. Procedia Economics and Finance, 12(March), 587-596. https:/ / doi.org/10.1016/s22125671(14)00383-9

Salma, L., \& Younes, B. (2014). Market power vs. financial stability: evidence from the MENA region's Islamic and conventional banking industries. Int. J. Monetary Economics and Finance, 7(3). https://doi.org/10.1504/ IJMEF.2014.066495

Sari, N. K., \& Widaninggar, N. (2018). Efisiensi Bank dalam Kelompok BUKU 4 di Indonesia: Pendekatan Data Envelopment Analysis. AFRE (Accounting and Financial Review), 1(2), 86-92. https://doi.org/ 10.26905/afr.v1i2.2409

Shawtari, F. A., Ariff, M., \& Abdul Razak, S. H. (2019). Efficiency and bank margins: a comparative analysis of Islamic and 
conventional banks in Yemen. Journal of Islamic Accounting and Business Research, 10(1), 50-72. https://doi.org/10.1108/ JIABR-07-2015-0033

Sitompul, S., \& Nasution, S. K. (2019). The Effect of Car, BOPO, NPF, and FDR on Profitability of Sharia Commercial Banks in Indonesia. Budapest International Research and Critics Institute (BIRCI-Journal): Humanities and Social Sciences, 2(3), 234-238. https://doi.org/10.33258/birci.v2i3.412

Statistik Perbankan Indonesia. (2018). 17, 01.

Statistik Perbankan Indonesia. (2019). 17(07).

Subandi, \& Ghozali, I. (2013). Determinan efisiensi dan dampaknya terhadap kinerja profitabilitas industri perbankan di indonesia. Jurnal Keuangan Dan Perbankan, 17(1), 123-135.

Sukarno, K. W., \& Syaichu, M. (2006). Analisis Faktor-Faktor Yang Mempengaruhi Kinerja Keuangan Pada Bank UmumDi Indonesia. Jurnal Studi Manajemen \& Organisasi, 3(2), 46.

Susantun, I., Mifrahi, M. N., \& Sudarsono, H. (2019). Analisis resiko likuiditas bank syariah. Conference on Islamic Management, Accounting, and Economics (CIMAE), Volume. 2, 111-118.

Sutawijaya, A., \& Lestari, E. P. (2009). Efisiensi Teknik Perbankan Indonesia Pascakrisis Ekonomi: Sebuah Studi Empiris Penerapan Model Dea. Jurnal Ekonomi Pembangunan: Kajian Masalah Ekonomi Dan Pembangunan, 10(1), 49. https://doi.org/10.23917/ jep.v10i1.808

Thalib, D. (2016). Intermediasi, Struktur Modal, Efisiensi, Permodalan Dan Risiko Terhadap Profitabilitas Bank. Jurnal Keuangan Dan Perbankan, 20(1), 116-126. https://doi.org/ 10.26905/jkdp.v20i1.155

Widiarti, A. W., Siregar, H., \& Andati, T. (2015). the Determinants of Bank'S Efficiency in Indonesia. Buletin Ekonomi Moneter Dan Perbankan, 18(2), 129-156. https://doi.org/ 10.21098/bemp.v18i2.520

Wijayanto, A., \& Sutarno. (2010). Kinerja Efisiensi Fungsi Intermediasi Bank Persero Di Indonesia Dengan Menggunakan Data Envelopment Analysis (DEA). Jurnal Keuangan Dan Perbankan, 14(1), 110-121.

Yusniar, M. W. (2011). Analisis Efisiensi Industri Perbankan di Indonesia Dengan Pendekatan Data Envelopment Analysis (DEA) dan Faktor-Faktor yang
Mempengaruhinya. Jurnal Manajemen $\mathcal{E}$ Bisnis, 1(2), 175-195.

Zahra, N., \& Darwanto, D. (2019). The Determinant of Banking Efficiency (Data Envelopment Analysis Based on Intermediation Approach). Jurnal Ekonomi Pembangunan: Kajian Masalah Ekonomi Dan Pembangunan, 20(1), 87-99. https://doi.org/ 10.23917/jep.v20i1.5799

Zaini, M., Karim, A., Chan, S., \& Hassan, S. (2010). Bank Efficiency and NonPerforming Loans: Evidence From Malaysia and Singapura. Prague Economic Papers:118132. 